\title{
MODELLING AND STUDY THE EFFECT OF SELECTED DESIGN FEATURES FOR THE OPERATING PARAMETERS OF INDUSTRIAL ELECTROSTATIC PRECIPITATORS
}

\section{MODELOWANIE I BADANIA WPEYWU WYBRANYCH CECH KONSTRUKCYJNYCH NA PARAMETRY EKSPLOATACYJNE ELEKTROFILTRÓW PRZEMYSŁOWYCH*}

\begin{abstract}
Electrostatic precipitators are currently most commonly used in industrial processes equipment to reduce dust emissions into the atmosphere. A significant impact on the process of extraction of two-phase gas/dust medium has the shape and configuration of the discharge electrodes, affecting the shape of the electric field in the chamber electrostatic precipitator. Geometric parameters of discharge electrodes and their arrangement in the chamber electrostatic should provide uniform current density distribution at the surface of the collecting electrodes. The article presents an analysis of the impact of geometry and configuration of industrial - blade type discharge electrodes on the distribution of current density on the collecting electrode. On the basis of the measurement results mathematical model was worked out which allows simulation of the current density distribution depending on the shape of the electrodes. The model allows to specify the most appropriate parameters of distance between the emission elements of discharge electrode and the distance between the electrodes. Preferred geometric parameters and configuration of discharge electrodes was determined by analyzing power spectral density magnitude (PSD) and the mean square value (RMS) of current density. The results indicate the possibility of reducing the number of elements of emission corona electrodes without worsening of the operating parameters of electrostatic precipitator.
\end{abstract}

Keywords: electrostatic precipitator, operation, corona electrodes, modeling, simulation, sigmoidal function.

\begin{abstract}
Elektrofiltry sa obecnie najcześsciej stosowanymi, w procesach przemystowych, urzadzeniami do redukcji emisji pyłów do atmosfery. Znaczacy wplyw na przebieg procesu odpylania ośrodka dwufazowego gaz/pyt ma kształt oraz konfiguracja elektrod emisyjnych, wptywajace na uksztaltowanie pola elektrycznego w komorze elektrofiltru. Parametry geometryczne elektrod ulotowych oraz ich rozmieszczenie w komorze elektrofiltru powinny zapewniać równomierny rozkład gęstości prądu na powierzchni jego elektrod zbiorczych. W artykule przedstawiono analize wptywu geometrii oraz konfiguracji przemysłowych elektrod ulotowych typu ostrzowego na rozkład gesstości pradu na elektrodzie zbiorczej. Na podstawie wyników pomiarów opracowano model matematyczny umożliwiający symulację rozkładu gęstości tego prądu w zależności od ksztattu elektrod. Model umożliwia określenie korzystnych wartości odległości pomiędzy elementami emisyjnymi elektrody ulotowej oraz odległości pomiędzy tymi elektrodami. Korzystne parametry geometryczne i konfigurację elektrod ulotowych określano na podstawie analizy magnitud gęstości widmowej mocy (PSD) oraz wartości średniokwadratowej (RMS) gęstości prądu. Uzyskane wyniki wskazuja na możliwość zmniejszenia ilości elementów emisyjnych elektrod ulotowych bez pogorszenia parametrów eksploatacyjnych elektrofiltru.
\end{abstract}

Stowa kluczowe: elektrofiltr, eksploatacja, elektrody ulotowe, modelowanie, symulacja, funkcja sigmoidalna.

\section{Introduction}

Electrostatic method of purifying of exhaust gases is widely used in heating energy, metallurgy, chemical, cement and paper industry [20]. However the main sector of the economy, which use of electrostatic dust removal equipment, is energy production industry using electrostatic processes for cleaning gases generated by the combustion of different types of fuels [17]. Combustion gases contain significant amounts of dust. In power industry, the only reasonable solution from the economic point of view is to use precipitators with horizontal plate structure due to the amount of exhaust gases generated during energy production.

Electrostatic precipitators are structures suitable for use in the well-defined power plant installation. Selection of precipitator design, type of corona and collecting electrodes used $[1,2]$ and power supply system are determined by the type of boiler and type of boiler fuel burned in it, and consequently by the properties of dusts which will be separated. At the stage of design the base exploitation parameters are defined i.e. guaranteed parameters and limiting parameters values defined by:

- fuel (including elemental composition, sulfur content, calorific value, ash content)

- combustion gases (minimum and maximum flow rate, humidity, temperature, dew point temperature, the content of $\mathrm{CO}_{2}$ and $\mathrm{O}_{2}$ ),

- dust (nominal and maximum concentration, the maximum content of flammable particles).

The main task of electrostatic precipitator is separation dust phase from the combustion gases, therefore the most important parameter is

(*) Tekst artykułu w polskiej wersji językowej dostępny w elektronicznym wydaniu kwartalnika na stronie www.ein.org.pl 
the value of the dust emission at its output. For newly constructed facilities, depending on the fuel, concentration level of pollutants at the output of an electrostatic precipitator do not exceeds: for coal or lignite $5 \div 15 \mathrm{mg} / \mathrm{m}^{3}$, and for biomass and peat 5 to $20 \mathrm{mg} / \mathrm{m}^{3}$ of dry combustion gases in the contractual conditions (content of water vapor is not larger than $5 \mathrm{~g} / \mathrm{kg}$ of combustion gas in the reference conditions of $\mathrm{O}_{2}=6 \%$ ). This means, that for example, the concentration of dust in the exhaust gases from the combustion of coal $d_{C}=26 \mathrm{~g} / \mathrm{m}^{3}$ dust collection efficiency of the electrostatic precipitator must be $99.96 \%$.

Fuel characteristics, exhaust gas properties and the amount of dust in them determine the choice of construction solution of electrostatic precipitator:

- size, number of sections and zones of extraction, the active height and length of the electric field, the number of power supplies and independently powered electrostatic fields, etc.,

- the nominal gas flow rate (approx. $1 \mathrm{~m} / \mathrm{s}$ ),

- a decrease in temperature and pressure of the gas in the electrostatic precipitator (respectively: $5 \div 10{ }^{\circ} \mathrm{C}, 120 \div 150 \mathrm{~Pa}$ ),

- the layout, type and number of discharge and collecting electrodes,

- type and number of employed rappers of collecting and corona electrodes.

During the operation in the stable condition the basic operating parameters of electrostatic precipitator are electrical parameters resulting from the type of the high-voltage power supplies, i.e. voltage and nominal current. Currently are in use power supplies with the following output parameters; current / voltage, 400 $\div 2000 \mathrm{~mA}, 80 \div 135$ $\mathrm{kV}$, respectively. The significant influence to meet the requirements on the dust emissions output of electrostatic precipitator have:

- voltage supply of corona electrodes,

- tuning of the high voltage supply control unit (operation mode),

- the frequency of the shake off the dust being deposited on the collecting and corona electrodes.

Significant impact on the course of the dust deposition process on collecting electrodes has the shape and configuration of the discharge electrodes affecting the shape of the density distribution of the electric field in the chamber electrostatic precipitator. The current density on the surface of the collecting electrode affects the mechanical properties of the deposited dust layer on the surface of the collecting electrode. The value of current density at the surface of the collecting electrode is affected by the emissivity of the electrode and the conductance two-phase medium present in the interelectrode space in case of particular electrode configuration. In the operating process of an electrostatic precipitator, both of these parameters are determined by the selection of the supply voltage of the corona electrodes and operation parameters of high voltage power suppliers, at a level that prevents the phenomenon of migration of dust grains detached from the surface of collecting electrode further into the electrostatic precipitator.

In the past 20 years there have been significant changes in the structure of the discharge electrodes of electrostatic precipitators. Due to the low durability wire and tape electrode were abandoned. An important advantage of this type of electrode was uniform and relatively easy to calculate distribution an electrostatic field produced by them. Currently, there are mast type electrodes equipped with point emission elements in the form of spikes. Complex distribution of electric field around such electrodes prevents the use in theoretical analysis, mathematical models developed for the wire electrodes.

The development of information technology has enabled the use of numerical methods for modeling the phenomena occurring in the interelectrode space of electrostatic precipitator [3, 4, 5, 9, 11, 12, 23]. The next step in the development of computer simulation of the dust separation process in the electrostatic precipitators were attempts to develop alternative models of discharge electrodes [7, 21]. Of great importance for the quantitative determination of the phenomena occurring during the discharge in the environment of gases (the degree of ionization to be calculated from the functions of the energy distribution of electrons) and the speed of propagation of the corona are the results of work in the field of plasma physics [10]. Computer simulation of the electric field parameters and its impact on the process of dust separation, is facing difficulties due to the complex geometry of the currently used corona electrodes. There are still experimental research conducted, on the basis of which it can be concluded about the process of two-phase medium dedusting, which are the combustion gases [13, 14].

This paper presents the results of research carried out on industrial spike type corona electrode. An example of construction of this type electrode is shown in Fig. 1.

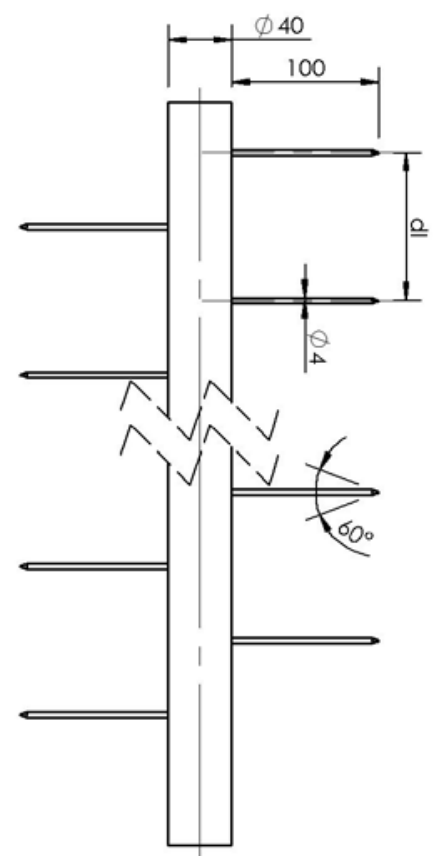

Fig. 1. Mast type spike corona electrode

Mast spike electrode consists of a carrier mast having a diameter of about $40 \mathrm{~mm}$ and the emission elements, which are steel bars with a diameter of $4 \mathrm{~mm}$ and length $100 \mathrm{~mm}$, welded to the mast at the opposite sides at appropriate intervals. Emission elements are terminated with cone tip.

\section{Research Methodology}

Measurements of the electrical parameters of discharge electrodes was performed on the test stand shown in Figure 2 [16]. Depending on the configuration, current-voltage characteristics of the electrodes and the current density on the surface of the collecting electrode can be determined. High of the active part of the collecting electrodes is $h=1.0 \mathrm{~m}$ and maximum division of the collecting electrodes is $H_{z}=$ $0.6 \mathrm{~m}$ so the measuring stand allows industrial research corona electrode of a length of $0.8 \mathrm{~m}$ to be tested. It consists of a support frame (1), to which the collecting electrodes with a total area of $4 \mathrm{~m}^{2}$ (2) are fixed. The tested discharge electrode is attached to the insulated inner carrier frame (3) and supplied with a DC high voltage power supply. Measurement signals from the sensors (4) are transmitted through the connector (5) to the measurement and data acquisition systems. Measurement of the current density distribution at the surface of the collecting electrode is performed using sixteen measuring fields (4) equally distributed along the length of the collecting electrode. The 
currents flowing between each of the measurement fields and the ground are sequentially selected by the 1 of 16 multiplexer and send to one of the measuring amplifier. Data acquisition and multiplexer control are made using specially prepared software based on LabView package. Registered voltage value is obtained by averaging the 2000 samples for each of the measurement fields. Data are recorded five times in the cycle, which means that the measured value of the current corresponding to the value of the current flowing through each of the measurement fields, is the mean value of 10000 measurements.
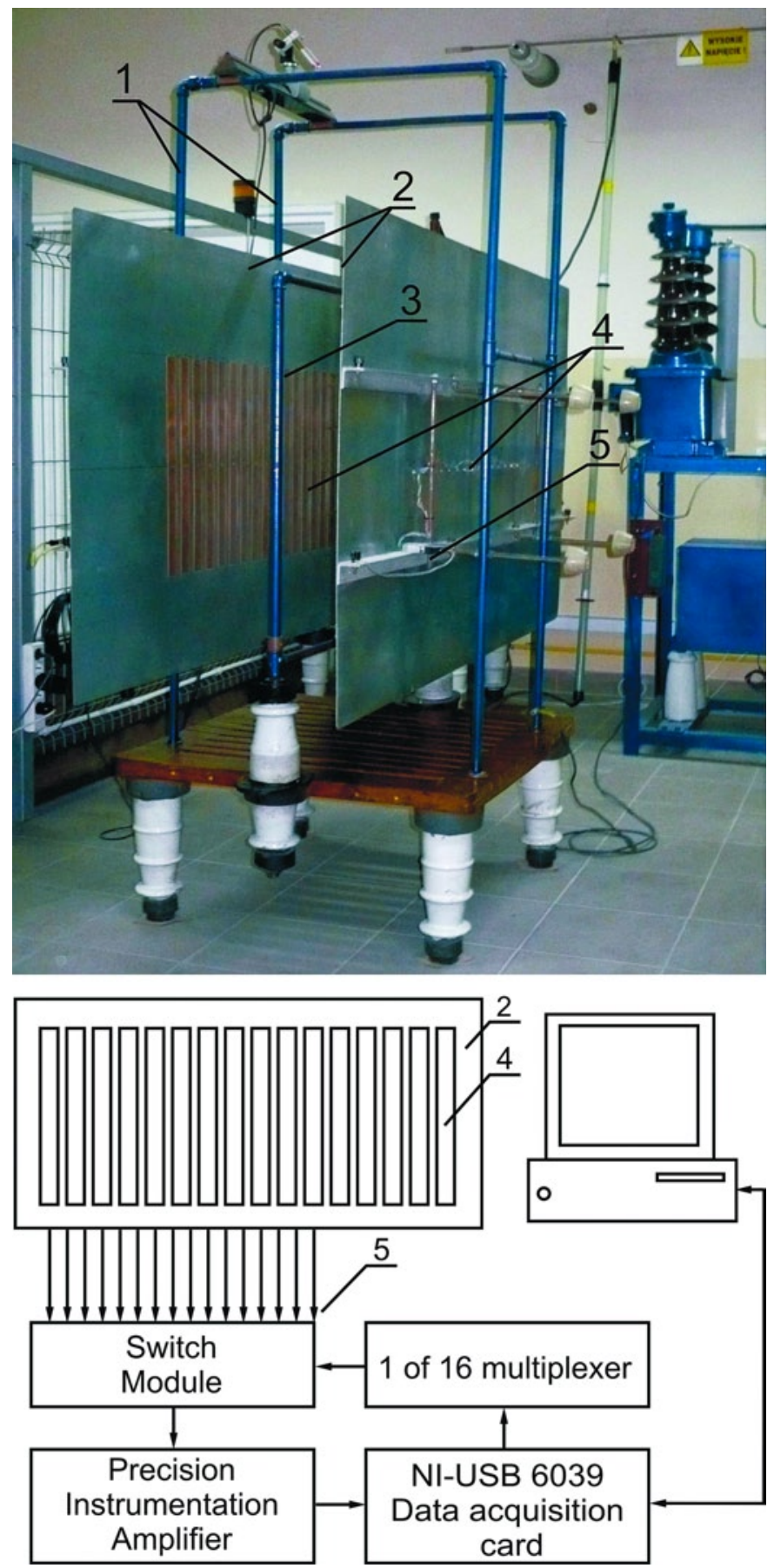

Fig. 2. The measuring stand used to determine the parameters of the corona electrode 1 - supporting frame, 2 - colecting electrodes, 3 - corona electrode support frame, 4 -sensors, 5 -electrical connectors

The analysis of measured electric parameters of the electrodes was carried out using tools developed for time series analysis. The use of statistical methods of time series analysis simplifies the analy- sis of the results obtained in the measurement of electrical parameters of studied electrodes. It also provides information about the tested object, which cannot be obtained by other methods. For the analysis of the current distribution on the surface of the collecting electrode research methodology based on the formalism of statistical time series model was applied [6]. Analysis of the current density distribution on the surface of the collecting electrode was performed using developed for this purpose software with advanced statistical functions, serving for time series analysis TSA (Time Series Analysis), a component of LabView software [24]. This program, after initial processing of the measured data allows their smoothing and calculation of the following parameters:

- the average value after elimination of extreme values,

- the mean square value RMS (Root Mean Square),

- magnitude of the power spectrum PS (Power Spectrum) to be calculated using the algorithm of fast Fourier transform FFT (Fast Fourier Transform) of the current density on the surface of the collecting electrode in the form of the squares of the $R M S$ values,

- power spectral density PSD (Power Spectrum Density) FFT of the time series $X t$ (in the form of squares of the $R M S$ values per unit of the $\mathrm{x}$-axis of collecting electrode).

For the calculation of the power spectrum and power spectral density the procedures contained in the libraries of functions built in LabView program were used.

The simplified algorithm of the program to analyze the measured data with the LabView procedures is shown in Figure 3.

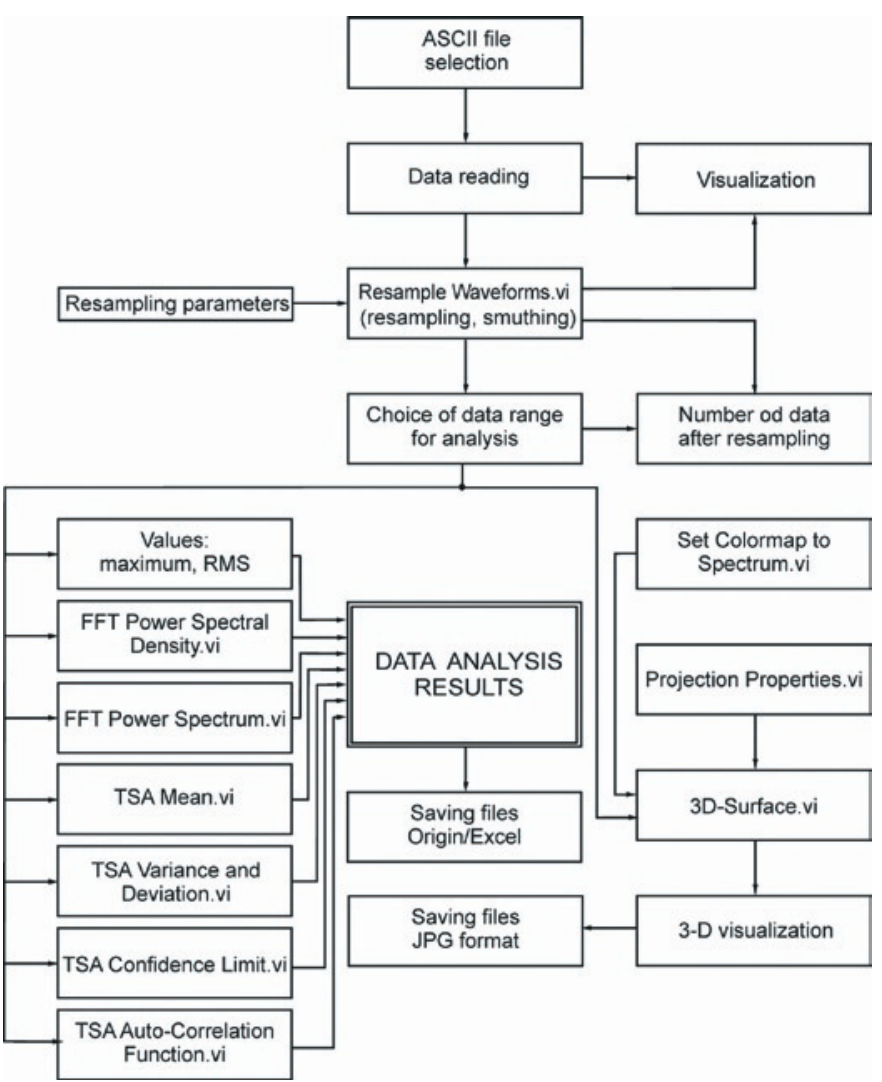

Fig. 3. Algorithm of the program to analyze the current density distribution measurements on the surface of the collecting electrode

Research on the dust separation process using industrial corona electrodes and electrodes with modified geometry was carried out in the laboratory electrostatic precipitator (Fig. 4) with the following parameters:

- the active length of the chamber: $2 \mathrm{~m}$,

- the height of chamber: $1 \mathrm{~m}$, 


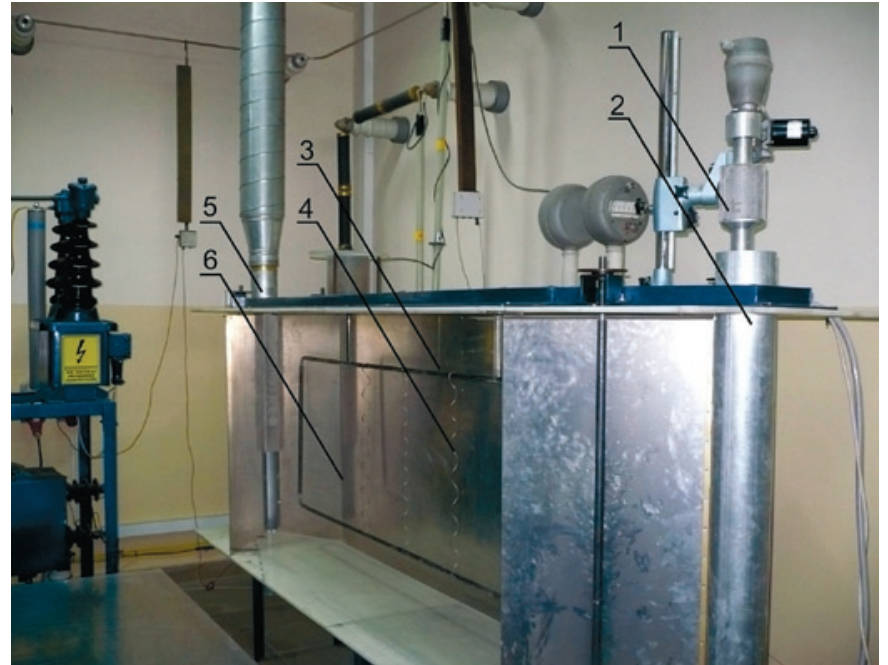

Fig. 4. View of laboratory electrostatic precipitator with removed collecting electrode. 1 - the dust feed system, 2 -diffuser, 3 -frame of discharge electrodes, 4 -discharge electrode, 5 - confusor, 6 - collecting electrode

- the inter-pitch: $400 \mathrm{~mm}$ or $500 \mathrm{~mm}$,

- collecting electrodes: flat,

- corona electrodes: replaceable, matched to spe cific measurements,

- gas flow rate: $0.1 \mathrm{~m} / \mathrm{s}$ to $0.8 \mathrm{~m} / \mathrm{s}$,

- a source of dust: fluidized bed chamber fed from a source of compressed air,

- administration of dust: a system of nozzles ar ranged vertically in the area of the inlet of the electrostatic precipitator.

Electrostatic corona electrodes are powered by a DC power supply with high voltage enables a smooth adjustment of the voltage from 0 to $75 \mathrm{kV}$.

The air flow through the electrostatic precipitator chamber was obtained through the use of suction fan powered by a frequency converter. The motor speed changes influence the performance of the fan, and thus the speed of air flow through the chamber electrostatic precipitator.

\section{Results}

\subsection{The results of measurements of the electrical param- eters of discharge electrodes}

Studies of electrical parameters of discharge electrodes are made under the following conditions: temperature $t=21^{\circ} \mathrm{C}$, the relative air humidity $a_{h}=52 \%$, barometric pressure $p=991.9 \mathrm{hPa}$.

Examples of current density distribution at the surface of collecting electrode for assembly of two spike electrodes for the variable distance between electrodes $H$ is shown in Figure 5 .

Figure 6 shows the cumulative results of the relationship between magnitude of power spectral density $P S D$ and the $R M S$ value as a function of distance between charging electrodes $H$ and spike distance $d I$.

The results showed that increase the distance between the emission elements of the electrode, increases the current density $J$. Maximum value of the current occurs at a $d I=250 \mathrm{~mm}$. At the same time increase, the distance between the corona electrodes causes a decrease in the value of the current density on the surface of the collecting electrode.

Analysis magnitude of power spectral density PSD and of $R M S$ value as a function of the distance between corona electrodes $H$ and

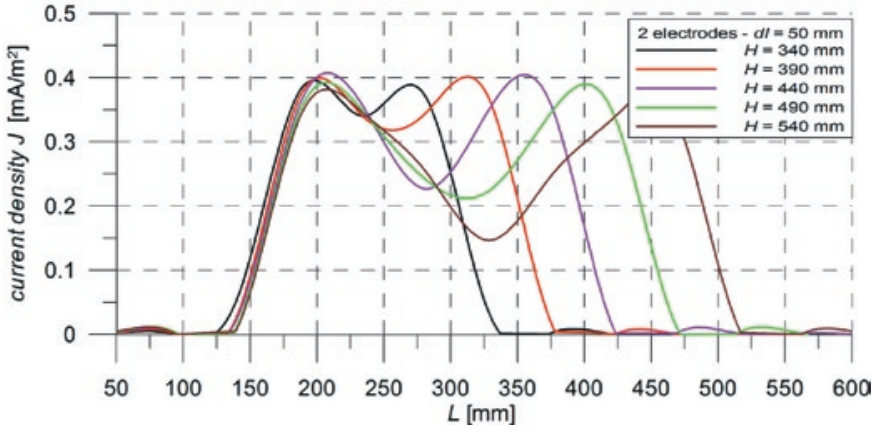

Fig. 5. Current density distribution of on the surface of the collecting electrode as a function of corona electrode space $H$. The distance between spikes $d I=50 \mathrm{~mm}$ and distance between collecting electrodes $\mathrm{Hz}=$ $400 \mathrm{~mm}$
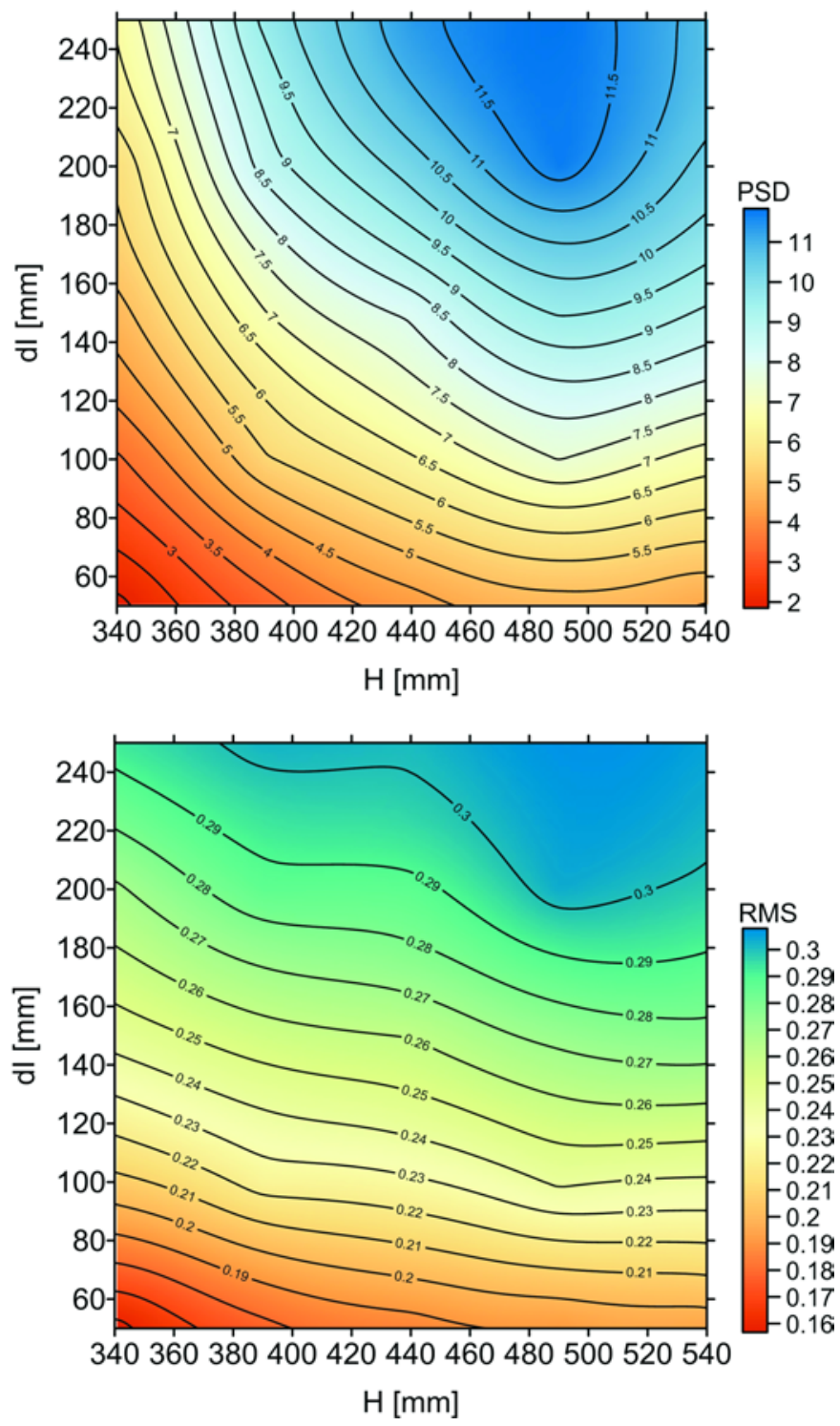

Fig. 6. The magnitude of power spectral density PSD and the RMS value of the current density $J$ as a function of distance between charging electrodes $H$ and spike distance $d I$.

emission elements of the charging electrode $d I$ indicate that both the increase in the distance between corona electrode and the distance between the emission electrodes result in an increase both the power spectral density and the $R M S$ current density for the tested electrodes. Areas with the highest values of the PSD and RMS indicate in blue 
color - Fig.6. The results indicate that with increasing distance between the corona electrodes maximum $P S D$ value of the current density distribution at the surface of the charging electrode corresponds to the $H=490 \mathrm{~mm}$.

\subsection{Mathematical formula describing the distribution of the electric field in the space between electrodes in the electrostatic precipitator}

Based on the measurement results a mathematical model of the current density distribution on the surface of the collecting electrode was developed. The measurement data of the current density distribution at the surface of collecting electrode $J$, depending on the $H$ parameter and $d I$ parameter $(d I$ is the distance between emission elements) were preliminary processed. The results of the measurements were subjected to statistical analysis to eliminate the extreme values and smoothing. To negative values of the current density $J$ zero value was assigned as zero value has no physical meaning. Then analyzed data $J$ were converted, depending on the geometric coordinates of $L$, ie. position along the collecting electrode, in such a way as to be symmetrical with respect to y axis. If the chart does not exhibit symmetry, the right site was replaced with the mirror image of the left. Figure 7 shows the result of the transformation of data in accordance with the accepted method of statistical analysis.

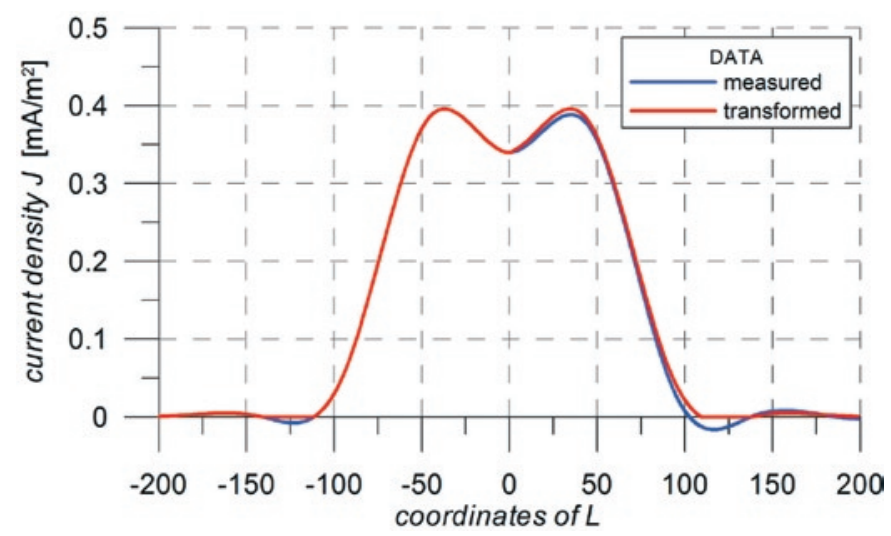

Fig. 7. Distribution of current density on the surface of collecting electrode. a) the data obtained from measurements, b) data after processing

The curve shown in Fig. 7 is the sum of two peaks with a distinct asymmetry. This pattern can be described by adding at least four symmetrical peaks with variable ratio Gauss/Lorentz [15]. However, for a general description of each peak number of parameters, such as halfwidth, amplitude ratio $\mathrm{H} / \mathrm{L}$ need to be introduced and jet linking them to the spatial distribution of the electrodes is essential. The number of parameters can be limited by using sigmoid function [19] for the description of the outlined curve. Therefore, to approximate the current density distribution at the surface of the collecting electrode composition of asymmetric sigmoid function was applied, resulting in an ability to model asymmetric waveform. The sigmoidal form of the equation is (1):

$$
y=y_{0}+A[1 /(1+\exp (-x+x c / w))]
$$

where:

$$
\begin{aligned}
& A \quad \text { - amplitude, } \\
& w, x c \text { - function parameters, } \\
& y_{0} \quad \text { - shift of the function value on the } y \text { axis. }
\end{aligned}
$$

Changing of $w$ parameter changes the slope of the curve, while the parameter $x c$ designate a point of inflection of the curve and allows to move the curve along the $x$ axis.
Superposition of two sigmoidal functions allow asymmetric spectra to be obtain if the $w 2$ and $w 3$ parameters will have different values. The superposition of the two sigmoidal function can be written (2):

$y=y_{0}+A[1 /(1+\exp ((-x+x c-w 1 / 2) / w 2))] \cdot[1-1 /(1+\exp ((-x+x c-w 1 / 2) / w 3))]$

where:

$$
x c, w 1, w 2, w 3, x c-\text { function parameters. }
$$

Parameter $w 1$ modifies the value of the parameter $x c$ and allows to change the half-width of the peak.

In case of two corona electrode assembly, the distribution of current density $J$ on the surface of collecting electrode (Fig. 7), can be described by the sum of two asymmetric functions (3):

$J y_{0}+A l[1 /(1+\exp ((-x+x c 1-w 11 / 2) / w 21))] \cdot[1-1 /(1-\exp ((-x+x c 1-w 11 / 2) / w 31))]+$ $+A 2[1 /(1+\exp ((-x+x c 2-w 12 / 2) / w 22))] \cdot[1-1 /(1-\exp ((-x+x c 2-w 12 / 2) / w 32))]$

where:

$A 1, A 2$ - amplitude,

$w 11, w 12, w 21, w 22, w 31, w 32,-$ parameters of the function,

$x c 1, x c 2 \quad$ position of the peak's maximum on the $x$-axis,

$x c 1$ parameter defines the position of the maximum of the first peak on the $x$ axis and can be selected arbitrarily.

As corona electrodes have, the same geometric design features so the two peaks of the spectra should be symmetrical with respect to an axis passing through the center of the curve (Fig. 7.). Any variations in the current density distribution at the collecting electrode are due to inaccuracies of electrode manufacturing. On the basis of experimental data analysis and the symmetry condition it was assumed that the coefficients $A 1=A 2=A, y_{0}=0, W 11=W 12=w 1, w 21=w 32$ and $w 31=$ $w 22$. These factors are functions of the following parameters: distance between the corona electrodes $H$, and the distance between the emission elements $d I$.

The assumption of fixed numerical values for the $w 1, w 21$, and $w 22$ coefficients, gives rise to slight discrepancies between the actual values obtained from the measurements and the values calculated using a mathematical model but this leads to a significant simplification of the model and reduce the number of variables.

Analysis of the measured data showed that in the case of $H_{Z}=400$ $\mathrm{mm}$, the influence of the $d I$ distance and corona electrodes distance $H$ on the parameters: $w 21$ and $w 22$ are small and neglectable. In order to reduce the number of coefficients, the following simplifying assumptions have been made: $w 21=w 32=w 31=1.5$ and at $w 22=2.6$.

After substituting these values to the function (3) it simplifies to the form (4):

$J(x, H, d I)=A[1 /(1+\exp (-x+x c 1-(w 1 / 2) / 1.5))] \cdot[1-1 /(1+\exp (-x+x c 1-(w 1 / 2) / 2.6))]+$ $+A[1 /(1+\exp (-x+x c 2-(w 1 / 2) / 2.6))] \cdot[1-1 /(1+\exp (-x+x c 2-(w 1 / 2) / 1.5))]$

As a result of adopted assumptions, to describe the distribution of current density $J$ at the surface of the collecting electrode three variables depending on the scale parameter $H$ and the scale, $d I$ i.e. function coefficients (4): $A, x c 2$, and $w 11$ must be determine.

According to equation (3) changing $x c 1$ parameter affects the position of the curve with respect to the $x$ axis. The value $x c 1$ was assumed arbitrarily $x c 1=20$. This allows a comparison of the current density distribution $J$ on the surface of the collecting electrode obtained from measurements with the results determined according to the mathematical model.

Figure 8 shows a measured data of current density distribution $J$ approximated with the function (4) in case of spike-type electrode. 


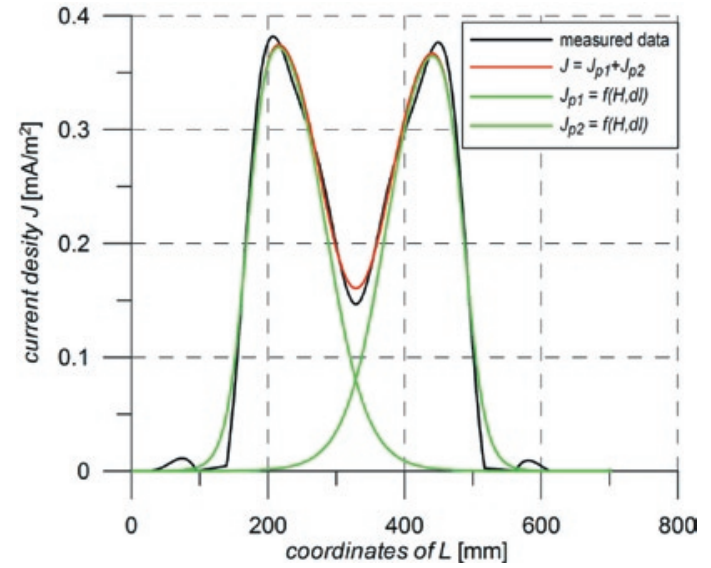

Fig. 8. Approximation using function (4) measured data of current density $J$ for the spike corona type electrodes

Table 1 shows the coefficients of the function describing the current density distribution $J$ on the collecting electrode.

Table 1. Function coefficients $J=f(x, H, d l)$ for the spike electrodes

\begin{tabular}{|c|c|}
\hline Function coefficient & Value/Function \\
\hline$w 21$ & 1.5 \\
\hline$w 31$ & 2.6 \\
\hline$x c 2$ & $x c 1-10.634+0.0565 \cdot H+0.0073-d l \cdot 4.2857 \mathrm{e} \cdot 5-d l^{2}$ \\
\hline$A$ & $-0.717+0.00485 \cdot H-5.0655 \mathrm{e}-6 \cdot H^{2}+1.21 \mathrm{e}-3 \cdot d l$ \\
\hline$w 1$ & $14.0434-0.0415 \cdot H+0.003 \cdot d l-2.0 \mathrm{e}-5 \cdot d l^{2}$ \\
\hline
\end{tabular}

The mathematical model that describes the distribution of current density $J$ at the collecting electrode was verified by comparing the measurement results with the results obtained by theoretical simulation. Simulations were performed assuming variable coefficients of function (4) shown in Table 1. The simulated spectra of the current density and the recorded spectra were analyzed seeking to establish their convergence. This allowed to say what impact have simplifying assumptions in the model adopted on the real physical phenomena occurring in the space of electrostatic precipitator.

Figure 9 shows an example of a comparison of the distribution of measured current density $J$ at the collecting electrode with the simulated one.

Black curve shows the measurement results obtained by means of approximation of the measured data using the least-squares Marquardt-Levenbergera algorithm [18]. The curve marked red shows the progress generated by the simulation using the model described by equation (4), for the assembly of spike corona electrodes at the two extremes of the $H$ scales.
The assessment of coincidence of the model with measured data, was performed by comparing the mean square value $R M S$, the value $I$ of the area (5) delimited by the current density $J$ distribution curve of and the $x$-axis, of the data derived from measurements with the current density distribution $J$ values obtained by simulation.

$$
\begin{aligned}
I_{H, d I}= & \int_{0}^{L} J_{H, d I}(x) d x, \\
& 0<L \leq 70 .
\end{aligned}
$$

The calculations were performed using the procedure of integration and calculation of the $R M S$ values using mathematical procedures from the libraries of National Instruments LabView software. Comparison of the current density distribution $J$ on the surface of the collecting electrode obtained by simulation using a mathematical model with the measurement data obtained in the laboratory showed that the differences between the measured data and simulated one for most of the analyzed geometry and configuration are less than $10 \%$ (table 2).

Table 2. Comparision of measured data with simulated one

\begin{tabular}{||c|c|c|c||}
\hline $\begin{array}{c}\text { H.dl values } \\
(\mathrm{mm})\end{array}$ & $\begin{array}{c}I_{\text {H.dl }} \text { value } \\
\text { (measured } \\
\text { data) }\end{array}$ & $\begin{array}{c}I_{\text {H.dl }} \text { value } \\
\text { (simulation) }\end{array}$ & $\begin{array}{c}\text { Differences } \\
(\%)\end{array}$ \\
\hline $\mathrm{H}=340 . \mathrm{dl}=150$ & 6.227 & 5.961 & 4.46 \\
\hline $\mathrm{H}=340, \mathrm{dl}=200$ & 6.650 & 6.494 & 2.40 \\
\hline $\mathrm{H}=390, \mathrm{dl}=150$ & 7.082 & 6.986 & 1.39 \\
\hline $\mathrm{H}=390, \mathrm{dl}=200$ & 7.817 & 7.541 & 3.66 \\
\hline $\mathrm{H}=440, \mathrm{dl}=150$ & 7.715 & 8.054 & 4.20 \\
\hline $\mathrm{H}=440, \mathrm{dl}=200$ & 8.470 & 8.665 & 2.25 \\
\hline $\mathrm{H}=490, \mathrm{dl}=150$ & 8.676 & 9.136 & 5.04 \\
\hline $\mathrm{H}=490, \mathrm{dl}=200$ & 9.710 & 9.839 & 1.31 \\
\hline $\mathrm{H}=540, \mathrm{dl}=150$ & 9.287 & 10.129 & 8.31 \\
\hline $\mathrm{H}=540, \mathrm{dl}=200$ & 9.993 & 10.960 & 8.82 \\
\hline
\end{tabular}

Assessing the compatibility of the mathematical model with the measurement results one should have in mind that the measurements were carried out on industrial corona electrodes. Some of these electrodes have a geometry errors resulting from the production technology. Taking into account that the developed mathematical model is used to assist in the designing of industrial electrostatic precipitators, where the geometry errors of corona electrode are quite high (manufacturing and/or assembly) the differences between the measurement results and obtained due to simulation are acceptable.
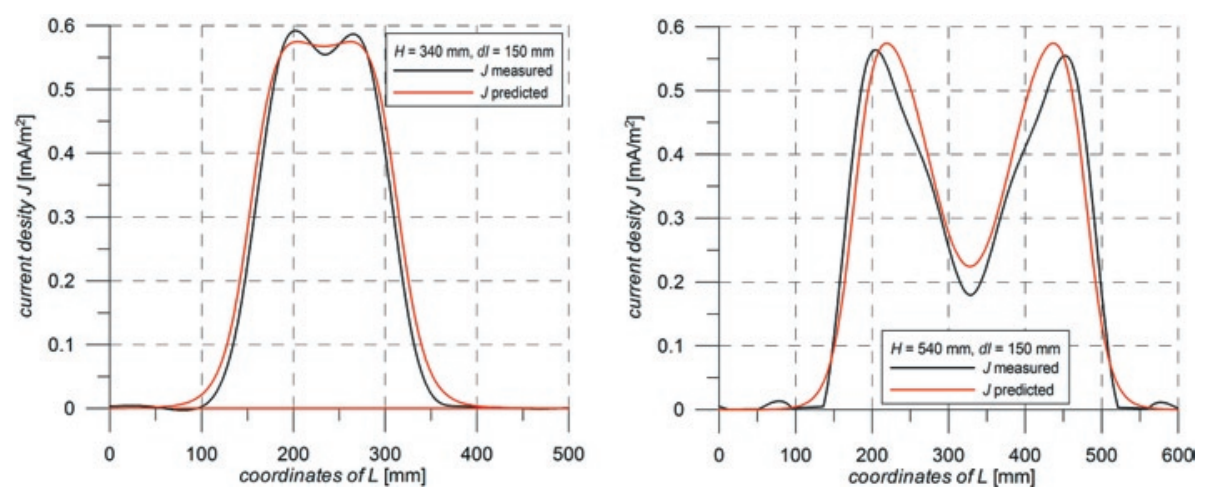

Fig. 9. Comparison of measured current density distribution data at the electrode with the spectra predicted by mathematical model

\section{Results}

Conducted laboratory studies have shown that the most important geometric parameter determining the electric field intensity produced by the spike corona electrode is the distance between emission elements (spikes) $d I$. Another important parameter is the distance between the emission electrodes $H$.

The current density distribution at the collecting electrode in case of mast type electrodes is depends on the value of spike distance $\mathrm{dI}$ and collecting electrode distance $H$. Most optimal ranges of these scales are determined by calculating the spectral density $P S$ changes as a function of $d I$ and $H$. Based on measurements and simulation studies, it was found that the range 
of the preferred spike distances $d I$ and collecting electrode distance $H$ in case of spike discharge electrodes are $200 \div 250 \mathrm{~mm}$ and $440 \div 550$ $\mathrm{mm}$ respectively. Predicted values are higher than those currently used in industrial electrostatic precipitators.

Worked out model of current density distribution on the surface of collecting electrode enables rapid determination of the electrical parameters of the spike type electrode. The results of simulation studies and carried out measurements of parameters of industrial spike electrodes showed that their geometry does not provide achievable current density. By changing the distance between the emission electrodes currently used (with spike distance $d I=200 \mathrm{~mm}$ ) it is possible to obtain increase in the magnitude of power spectral density PSD of the current on the surface of the collecting electrode by $10 \%$.

Study of the electrodes with modified geometry was carried out in the laboratory for the electrostatic precipitator using fly ash from coal combustion at concentrations of $3.4 \mathrm{~g} / \mathrm{m}^{3}$ and $7.2 \mathrm{~g} / \mathrm{m}^{3}$. Measurements carried out have shown that for the supply voltage $U_{S}=65 \mathrm{kV}$ average corona current value was $I_{E}=0.46 \mathrm{~mA}$. Comparison of the electrostatic precipitator performance equipped with currently used industrial electrodes, with the electrodes of the revised geometry showed no significant differences (in each case dusting efficiency approx. 99\%). The reason for this are both a small length and height of active part of laboratory precipitator. It should be recognized, however, that the increase in current density on the surface of collecting electrode providing an increase in the intensity of the electric field in the chamber electrostatic will result in the improvement in the dust separation. This means that for the corresponding parameters of power supply elimination of re-detachment of dust deposited on the collecting electrode due to loss of electrical charge or reduction the impact of this phenomenon on the process of extraction will take place. One may also believe that the above-described phenomena will allow to shorten the length of the electrostatic precipitator while maintaining the required removal efficiency.

The introduction of the proposed changes to the geometry of the discharge electrodes will not increase the efficiency of extraction of dust with diameter less than 2.5 microns $\left(\mathrm{PM}_{2.5}\right)$. Effective separation in the electrostatic precipitator of this grain fractions requires special technologies (agglomerators) [8, 22].

\section{Summary}

The results of measurements of the electrical parameters of discharge electrodes and a computer simulation of the current density distribution at the collecting electrode in case of electrostatic precipitator with flat system of collecting electrode showed that:

- Increasing the pitch (distance between electrodes): the interrow $H$ and inter-blades $d I$ of discharge electrodes, compared to the currently applied pitch, increases the amplitude of the current density,

- In the case of mast type electrodes one can obtained electric field, required for optimum extraction process, reducing the number of emission elements (blades) of the corona electrode,

- Increasing inter-row scale $H$ leads to reduction of the number of corona electrodes mounted in the chamber of electrostatic precipitator,

- The use of specified geometry and configuration of discharge electrodes will result in lower investment and operating costs of electrostatic precipitator in the range of energy consumption of the electrostatic precipitator.

\section{Acknowledgement \\ The work was financed by the statutory activities of the AGH University of Science and Technology in Krakow, Faculty of Mechanical Engineer- ing and Robotics, contract No. 11.11.130.957.}

\section{References}

1. Adamiec-Wójcik I, Nowak A, Wojciech S. Application of the finite strip method to modeling of vibrations of collecting electrodes. International Journal of Structural Stability and Dynamics 2013; 13(7): 1-19, http://dx.doi.org/10.1142/S0219455413400014.

2. Adamiec-Wójcik I, Nowak A, Wojciech S. Comparison of Methods for Modelling Vibrations of Collecting Electrodes in Dry Electrostatic Precipitators. Archive of Mechanical Engineering 2013; 60: 431-449, http://dx.doi.org/10.2478/meceng-2013-0027.

3. Akishev Y, Goossens O, Callebaut T, Leys C, Napartovich A, Trushkin N. The influence of electrode geometry and gas flow on corona-to-glow and glow-to-spark threshold currents in air. Journal of Physics D: Applied Physics 2001; 34: 2875-2882, http://dx.doi.org/10.1088/0022$3727 / 34 / 18 / 322$.

4. Atten A, Adamiak K, Khaddoura B, Coulomb J-L. Simulation of corona discharge in configurations with a sharp electrode. Journal of Optoelectronics and Advanced Materials 2004; 6(3): 1023-1028.

5. Batmunkh S, Battogtokh Z, Modeling an electrostatic precipitator (ESP) with ESPVI 4.0W. Second International Forum on Strategic Technology IFOST 2007: 650-653.

6. Box G E P, Jenkins G M. Time Series Analysis. San Francisco: Holden Day, 1976.

7. Brocilo D, Podlinski J,. Chang J S, Mizeraczyk J, Findlay R D. Electrode geometry effects on the collection efficiency of submicron and ultra-fine dust particles in spike-plate electrostatic precipitators. Journal of Physics 2008; 142: 1-6, http://dx.doi.org/10.1088/17426596/142/1/012032.

8. Chang Q, Zheng C, Gao X, Chiang P, Fang M, Luo Z, Cen K. Systematic Approach to Optimization of Submicron Particle Agglomeration Using Ionic-Wind-Assisted Pre-Charger. Aerosol and Air Quality Research, 2015, 2709-2719, http://dx.doi.org/10.4209/aaqr.2015.06.0418.

9. Chung L, Chang C.-L, Bai H. Effects of Some Geometric Parameters on the Electrostatic Precipitator Efficiency at Different Operation Indexes. Aerosol Science and Technology 2000; 33(3): 228-238.

10. Dubois D, Merbahi N, Eichwald O, Yousfi M, Benhenni M. Electrical analysis of positive corona discharge in air and N2, O2, and CO2 mixtures. Journal of Applied Physics 2007; 101: 053304-2-053304-9.

11. Fujishima H, Ueda Y, Tomimatsu K, Yamamoto T. Electrohydrodynamics of spiked electrode electrostatic precipitators. Journal of Electrostatics 2004; 62: 291-308, http://dx.doi.org/10.1016/j.elstat.2004.05.006.

12. Gooch J P, Francis N L. A Theoretically Based Mathematical Model for Calculation of Electrostatic Precipitator Performance. Journal of Air Pollution Control Association 1975; 25(2): 108-113, http://dx.doi.org/10.1080/00022470.1975.10470054.

13. Jędrusik M, Świerczok A. The correlation between corona current distribution and collection of fine particles in a laboratory-scale electrostatic precipitator. Journal of Electrostatics 2013; 71(3): 199-203, http://dx.doi.org/10.1016/j.elstat.2013.01.002. 
14. Jędrusik M, Świerczok A, Teisseyre R. Experimental study of fly ash precipitation in a model electrostatic precipitator with discharge electrodes of different design. Powder Technology 2003; 135-136: 295-301, http://dx.doi.org/10.1016/j.powtec.2003.08.021.

15. Kojima I, Kurahashi M. Application of asymmetrical Gaussian/Lorentzian mixed function for X-ray photoelectron curve synthesis. Journal of Electron Spectroscopy and Related Phenomena 1987; 42(2): 177-181. http://dx.doi.org/10.1016/0368-2048(87)85018-1

16. Machnik R., Nocun M. Effect of anti-corrosion coatings of corona electrodes on selected operating parameters of industrial electrostatic precipitators. Eksploatacja i Niezawodnosc - Maintenance and Reliability 2014; 16(1): 56-60.

17. Machnik R., Karwat B., Nocuń M., Niedźwiedzki J. Wpływ fizykochemicznych właściwości popiołów lotnych ze spalania węgli na proces elektrostatycznego odpylania spalin. Przemysł Chemiczny 2015; 94(9): 1530-1533.

18. Marquardt D, W. An Algorithm for Least-Squares Estimation of Nonlinear Parameters. Journal of the Society for Industrial and Applied Mathematics 1963; 11(2): 431-441, http://dx.doi.org/10.1137/0111030.

19. Ohishi K, Okamura H, Dohi T. Gompertz software reliability model: estimation algorithm and empirical validation. Journal of Systems and Software 2009; 82(3): 535-543, http://dx.doi.org/10.1016/j.jss.2008.11.840.

20. Parker K. Electrical operation of electrostatic precipitators., London: The Institution of Electrical Engineers, 2003.

21. Suleman M, Saleem M, Siebenhofer M. Characterization of brush type discharge electrodes and impact of enhanced corona discharge on operation of electrostatic precipitators. Journal of Electrostatics 2012; 70: 144-148, http://dx.doi.org/10.1016/j.elstat.2011.11.008.

22. Truce R, Wilkins J, Crynack R, Harrison W. The Indigo agglomerator a proven technology for reducing visible emission from electrostatic precipitators. Energetyka 2005, 11 (617) 751-757.

23. Zhao L, Adamiak K. Numerical Simulation of the Effect of EHD Flow on Corona Discharge in Compressed Air. IEEE Trans. on Industry Applications 2013; 49(1): 298-304, http://dx.doi.org/10.1109/TIA.2012.2228832.

24. National Instruments, LabView Advanced Signal Processing, Time Series Analysis Tools User Manual 2005.

\section{Bolesław KARWAT \\ Ryszard MACHNIK \\ Jerzy NIEDŹWIEDZKI}

AGH University of Science and Technology

Faculty of Mechanical Engineering and Robotics

al. Mickiewicza 30, 30-059 Kraków, Poland

\section{Marek NOCUŃ}

AGH University of Science and Technology

Faculty of Materials Science and Ceramics

al. Mickiewicza 30, 30-059 Kraków, Poland

E-mails: karwat@agh.edu.pl, machnik@agh.edu.pl, jniedz@agh.edu.pl nocun@agh.edu.pl 